\title{
Hidden Card untuk Meningkatkan Kompetensi Pragmatik Anak Prasekolah dalam Pembelajaran Kosa Kata Penguatan Pendidikan Karakter Bangsa
}

\author{
${ }^{1}$ Saptono Hadi, ${ }^{2}$ Agus Hermawan \\ Universitas Nahdlatul Ulama Blitar, Indonesia
}

Email: ${ }^{1}$ saptono656@gmail.com, ${ }^{2}$ agushermawan8992@gmail.com

\begin{tabular}{l}
\hline Tersedia Online di \\
\hline http://www.jurnal.unublitar.ac.id/i \\
ndex.php/briliant \\
\hline Sejarah Artikel \\
\hline Diterima pada 11 Mei 2020 \\
Disetujui pada 26 Mei 2020 \\
Dipublikasikan pada 30 Mei 2020 \\
Hal. 326-340 \\
\hline Kata Kunci: \\
\hline Hidden card; Penguatan; Usia dini \\
\hline DOI: \\
\hline http://dx.doi.org/10.28926/briliant. \\
v3i4.476 \\
\hline
\end{tabular}

\begin{abstract}
Abstrak: Riset ini berupaya mengungkapkan keefektifitasan media hidden card memacu kompetensi pragmatik anak didik Taman KanakKanak dalam memperbanyak kosakata tiga bahasa. Ancangan teori merujuk model pengembangan Arif S. Sadiman, melalui tahap (1) rancangan pengembangan; (2) prosedur pengembangan (dilakukan kajian rancangan hidden card); (3) aplikasi rancangan hidden card (teknis aplikasi, subjek hidden card, jenis-jenis data, alat pengambil data, teknis menganalisis data). Riset menyatakan bahwa terdapat peningkatan kompetensi pragmatik pada anak didik Taman Kanak-Kanak dalam memperbanyak kosakata/tuturan tribahasa (Bin, Bing, Baja Krama Inggil), dan hidden card sebagai media pembelajaran pemerolehan bahasa dapat merangsang anak didik memperbanyak kosakata.
\end{abstract}

\section{PENDAHULUAN}

Proses pendidikan merupakan komponen yang mempunyai kedudukan sentral. Anak usia dini/prasekolah merupakan masa sangat krusial dalam masa pertumbuhan dan perkembangan yang sangat membutuhkan bimbingan baik di rumah, di sekolah maupun dalam lingkungan pergaulannya. Diperlukan pembimbingan penanaman karakter sejak dini melalui pembiasaan perilaku keteladanan melalui penguatan pendidikan karakter sinergis orang tua baik dengan media pembelajaran maupun tidak. Menumbuhkembangkan nilai agama dan moral, sosial, emosional, baik koginitif, maupun perkembangan bahasa (pragmatik) akan membawa anak usia dini pada perkembangan fisik-motorik serta kreativitas anak sejak dini. Perkembangan itu tercermin melalui ujaran langsung dari apa yang dipikirkan, belum atau mampu memproses dan menyimpan informasi (keterampilan berbahasa), sebagai aplikasi komunikasi hubungan sosial kemasyarakatan.

Peneliti menemukan bentuk/cara pengkajian lain terkait pembentukan karakter anak asuh usia dini/prasekolah pada lembaga PAUD sebagai upaya memperkuat penguatan pendidikan karakter. Prasansti dan Fitriani (2018) dalam artikelnya menyatakan proses terbentuknya karakter AUD (anak usia dini) dapat ditekankan melalui pembelajaran keteladan melalui media dongeng sejak berada dalam lingkup keluarga, selanjutnya di sekolah, dan diperkuat dalam komunitas pergaulannya. Dalam artikelnya Sinaga (2018) juga menguraikan bahwa proses 
pembelajaran pendidikan karakter AUD perlu dilakukan sejak dini di lingkungan sekolah dengan berbagai media. Pembelajaran keteladanan karakter sejak dini dengan berbagai media bermain menurut Sinaga akan menumbuhkembangkan hasil yang maksimal atas perubahan karakter anak didik. Terkait karakter ini diperkuat tulisan Khaironi (2017) bahwa penekanan dan penanaman karakter dapat dilakukan melalui penguatan sikap perilaku akhlak terpuji nasihat keteladan guru pamong dalam pembelajaran. Peneliti lain, Zubaida (2018) menjelaskan upaya pembelajaran penanaman nilai-nilai akhlak teruji pada diri anak usia dini ini merupakan bagian dari pembentukan sebuah kepribadian akhlak-mulia anak sejak dini. Dan Khoironi (2018) menegaskan pembelajaran karakter ditekankan pada perkembangan agama-moral, sosial-emosional, pengembangan keterampilan bahasa (pragmatik), fisik-motorik, dan kreativitas sejak dini sebagai upaya terciptanya sumber daya manusia yang berkarakter akhlak terpuji.

Berdasarkan penelitian sebelumnya tersebut semakin meyakinkan bahwa pembelajaran penguatan pendidikan karakter sangatlah penting (krusial) dengan berbagai faktor yang berpengaruh dalam pembelajarannya. Jika para peneliti tersebut menggunakan media mendongeng dalam penguatan pembentukan karakter, maka peneliti sebagai upaya penguatan pendidikan karakter menggunakan media hidden card tri bahasa (bahasa Indonesia, Inggris, dan bahasa Jawa Krama Inggil). Tujuan penelitian ini mengkaji keefektifitasan anak didik Taman Kanak-Kanak dalam memperbanyak kosakata/tuturan dengan media hidden card sebagai media pembelajaran pemerolehan kosakata penguat karakter. Peneliti berkeyakinan bahwa media hidden card (visualiasasi) ini akan mempercepat pemerolehan bahasa (kosa kata) pada diri anak usia dini. Media hidden card merupakan salah satu media visual sekaligus media cetak. Media hidden card sebagai media visual mampu memberikan stimulus visual seperti mengingat, mengenali, mengingat kembali, menghubungkan antara konsep dan fakta, serta mampu memberikan stumulus secara verbal dengan cara memberikan hasil belajar apabila pembelajaran melibatkan ingatan yang berturt-turut. Semakin banyak kosa kata yang dimiliki anak usia dini, maka semakin mudah anak didik usia dini berinteraksi dalam pembelajaran. Selanjutnya meningkatnya kemampuan kompetensi pragmatik anak, maka proses pembentukan karakter (perkembangan agama-moral, sosial-emosional, pengembangan keterampilan bahasa (pragmatik), fisik-motorik, dan kreativitas sejak dini sebagai upaya terciptanya sumber daya manusia yang berkarakter ) pada diri anak mudah tercapai. Dengan pembimbingan pemahaman kosa kata pada anak-anak usia dini yang kompleks, mereka akan lebih mampu berkomunikasi karena kemampuan bahasa yang semakin meningkat dan memberikan kemudahan berbahasa yang lebih besar bagi anak untuk berinteraksi dengan lingkungannya (Otto, 2015: 198-199).

Selanjutnya kajian media pembelajaran hidden card sebagai, (1) upaya meningkatkan mutu penguatan pendidikan karakter sebagai kompetensi professional (basic competency), pengetahuan dan keterampilan mengajar dengan berbagai sumber media (auditif, visual, audio visual) sebagai metode pembelajaran sumber daya manusia; (2) keprofesionalan pendidik anak usia dini bukan sekedar mampu mengajari anak usia dini saja, namun dituntut mampu melakukan pengelolaan berbagai media belajar dalam KBM; (3) pembelajaran yang pasif dapat menyebabkan permasalahan perkembangan anak didik, perkembangan emosi, social, dan menghambat perkembangan fisik, intelektual, 
kognitif serta yang utama kemampuan berbahasa (pragmatik anak) untuk meningkatkan penguatan karakter budi pekerti: (4) permasalahan anak didik tidak mampu menirukan berbagai bahasa tertentu, tidak mampu menceritakan kembali kejadian, tidak mampu mengulang kembali urutan cerita, tidak mampu mendengar dengan baik dan memahami bahasa lisan yang diucapkan; dan (5) terdapatnya media hidden card sebagai media pembelajaran kosakata tribahasa (Bin, Bing, Baja Krama Inggil).

Kemanfaatan filosofis mendeskripsikan bahwa media pembelajaran hidden card ini memberikan pada anak didik keluasan dalam memilih berbagai gambar hidden card sesuai tema atau subtema yang diinginkan untuk mempermudah belajar (kongkrit). Nilai realistik atau kenampakan hidden card akan menanamkan dan tertanamnya konsep-konsep mandiri mengajak anak didik pola pikir karakter berpartisipasi sebagai pengamat kejadian dan pengalaman nyata. Selanjutnya secara teknologis-empiris dikatakan strategi/teknik pembelajaran merupakan bagian teori-teori dan praktik rancangan, pengembangannya, penerapan, tata kelola, evaluasi kegiataan belajar-mengajar serta media/sumber pembelajaran. Maksudnya bahwa tekno-edukasi dikatakan sebagai suatu sistem bersifat universal yang saling terkait antara komponenkomponen yang berpengaruh di dalamnya sesuai visi-misi (tujuan) yang terkontrol. Secara empiris kemanfaatan temuan kajian penelitian menunjukkan identifikasi kemajuan interaksi yang signifikan terhadap belajar anak. maksudnya bahwa penggunaan hidden card sebagai media pembelajaran mampu mendorong percepatan pemerolehan kosa kata anak dalam pemerolehanan bahasanya. Artinya, dengan hidden card sesuai karakter, maka anak didik usia dini memperoleh kemudahan dalam pembelajarannya (Satyana, 2007: 6-9),

Beberapa pola yang dapat digunakan dalam memanfaatkan media pembelajaran (Sadiman, 2002: 181-190), yaitu (1) penggunaan hidden card dalam kelas, artinya media hidden card digunakan untuk mengoptimalkan tercapainya visi, misi, dan tujuan; (2) penggunaan hidden card di luar ruang belajar, yakni (a) penggunaan hidden card secara terbuka, maksudnya hidden card pembelajaran dimanfaatkan anak didik usia dini sesuai kebutuhan masing-masing tidak dilakukan pengawasan atau control oleh guru pamong, tidak dituntut dalam proses pemahaman pada tingkat tertentu, baik umpan balik maupun dilakukan tes pemahamannya, (b) penggunaan hidden card terprogram, maksudnya bahwa hidden card sesuai kebutuhan masing-masing yang dimanfaatkan dalam kegiatan belajar-mengajar diatur sesuai sistemik pencapaian visi-misi-tujuan pembelajaran; (3) penggunaan hidden card (a) individual, maksudnya hidden card dimanfaatkan atau dirancang dengan tujuan untuk perorangan atau individual, sehingga dengan petunjuk yang ada seseorang dapat menggunakannya, (b) pemanfaatan media secara kelompok, maksudnya media pembelajaran ini dirancang untuk diberikan dan digunakan pada kelompok tertentu dengan jumlah yang disesuaikan dengan memenuhi persyaratan, pemanfaatan media secara massal, maksudnya media pembelajaran dirancang untuk digunakan pada orang dalam jumlah besar

Menurut Prismasari, strategi pragmatik dalam berkomunikasi pada anak usia dini dalam kegiatan belajar-mengajar perlu diperhatikan beberapa hal sebagai berikut: (1) terdapatnya proses tindak verbalism, maksudnya anak didik usia dini/prasekolah mampu mengatakan kalimat yang dimaksudkan, namun mereka tidak memahami makna yang dikandungnya. Proses terkait pemahaman ini 
disebabkan guru pamong anak usia dini dalam KBM sekedar membacakan atau menjelaskan, selanjutnya adanya kecenderungan anak usia dini ini sekedar plagiasi atau meniru yang diucapkan guru pamong sesuai kemampuan dasar anak; (2) penafsiran ganda, maksudnya kosa kata yang sama jika disebutkan ulang dimaknai beda. Salah tafsir ini terjadi pada anak didik usia dini karena guru pamong memberikan penjelasan dengan media hidden card namun tanpa pembanding hidden card lain atas subtema yang sama; (3) konten perhatian tidak berpusat, hal ini terjadi dasar titik-titik indikator masa pertumbuhan dan perkembangan anak usia dini/prasekolah (misal, terganggunya kesehatan badan, terdapatnya ketertarikan pada objek lain, anak didik termangu/melamun, guru terfokus satu kelompok, (4) faktor usia, maksudnya semua terkait pada tinjauan anak usia prasekolah dalam batasan dan keterbatasan pertumbuhan dan perkembangan kemampuan pemahaman cara berpikir kelogisan-pesikoloismenya terhadap dengan objek teramati, terlinat, teralami, dan dipelajarinya. Proses berpikir anak didik usia dini pada tahap ini belum mampu berlaku tindakan pola pikir logis sampai pada titian mengembangkan konseptual (Prismatasari, 2010:13).

\section{METODE}

Penelitian keefektifan hidden card ini menggunakan penelitian kualitatif, desain/rancangan yang merujuk pada model pengembangan Arif S. Sadiman, dengan teknik analisis diskursif. Teknik ini berfungsi untuk menerangkan fenomena meningkatnya kompetensi pragmatik anak usia dini.prasekolah TK PKK 1 dan Pertiwi Kota Blitar dalam pembelajaran kosa kata penguatan pendidikan karakter secara mendalam dengan memanfaatkan data perekaman, pencatatan, dan wawancara. Peneliti berlaku sebagai isntrumen kunci, dengan instrumen tambahan berupa pedoman pengamatan dan alat bantu pengamatan (perekam elektroki HP). Pengkaji secara leluasa memahami, mengidentifikasi, menganalisis, dan menafsirkan fenomena pemerolehan kosa kata tri bahasa anak usia dini. Kajian yang intens interaktif pengkaji dengan data tuturan beserta variabel keterkaitan pemerolehan kebahasaan anak usia dini TK PKK I dan Pertiwi merupakan kunci untuk memahami keefektifan pemerolehan kompetensi kosakata tri bahasa anak prasekolah/Taman Kanak-Kanak dwibahasawan JawaIndonesia. Pelaksanaan kajian mempertimbangkan bahwa faktor informasi pendataan dan fakta-fakta yang ditemukan bukan dipergunakan sebagai alat untuk membuktikan atau mempertentangkan teori (hipotesis) terdahulu, namun sebagai dasar pengkaji/peneliti membuat deskripsi tujuan kajian untuk selanjutnya tersusun hipotesis simpulan awal sampai ditemukan kesimpulan akhir penelitian sesuai tujuan penelitian.

Data penelitian yang diperoleh berupa pemerolehan kosakata tri bahasa (tuturan) anak prasekolah/Taman Kanak-Kanak dwibahasawan Jawa-Indonesia yang diujarkan dalam interaksi baik melalui action mandiri maupun banyak mitra. Pencatatan di lapangan terkait kompetensi pragmatik tindak tutur produk berkomunikasi dilakukan melalui pengamatan anak kelas B (21 anak, 12 laki-laki dan 9 perempuan) Taman Kanak-Kanak PKK I dan Pertiwi Kota Blitar, disertai nara sumber informan 3 guru pamong dan 3 pengasuh (mengetahui perkembangan anak asuh). Pengkaji berposisi instrumen kunci, maka pemahaman terhadap instrumen dan berbagai faktor yang berpengaruh pada proses kajian hanya dapat 
terpahami oleh pengkaji dan subjek teliti. Perekaman, pengamatan, dan pencatatan lapangan dilakukan untuk mengumpulkan data temuan. Temuan variabel yang mendukung kajian dilakukan analisis sebagai upaya mendeskripsikan fenomenafenomena keefektifan pemerolehan kosakata tri bahasa secara mendalam dengan memanfaatkan data perekaman, pencatatan di lapangan, dan wawancara (guru pamong dan pengasuh). Peneliti bersama guru pamong leluasa melakukan interpretasi rekaman percakapan. Penyeleksian bukti/data, kode, klasisfikasi, sajian, dan pengambilan benang merah simpulan merupakan bagian langkah penelitian. Analisis keefektifan media dilakukan dengan kriteria tingkat keefektifan perkembangan pemerolehan kosa kata. Pengelolaan data dalam pengembangan media hidden card dengan menginterpretasi hasil komprehensif asesment akhir perkembangan pembelajaran anak didik usia dini pra belajar dan akhir pembelajaran dengan hidden card.

\section{HASIL}

\section{Keefektifan Media Pembelajaran Hidden Card Memperbanyak Kosakata/Tuturan Tiga Bahasa Anak Usia Dini}

Identifikasi keefektifitasan pemerolehan bahasa anak didik Taman Kanak-

Kanak PKK 1 dan PKK Pertiwi Kota Blitar dalam memperbanyak kosakata/tuturan tribahasa (Bin, Bing, Baja Krama Inggil) dengan media pembelajaran hidden card tampak terurai pada tingkat pencapai perkembangan peningkatan kosa kata anak yang dilalui secara bertahap dengan teknis pembelajaran melalui bernyanyi dan dialog guru dan siswa. Pembelajaran dilakukan secara bertahap dengan menggunakan tiga bahasa secara berurut di mulai dengan menggunakan bahasa Indonesia, bahasa Jawa Krama Inggil, selanjutnya bahasa Inggris dengan media hidden card sebagai media verbal. Data capaian perkembangan anak dalam beretika (karakter) menunjukkan bahwa semakin banyak kosa kata atau tuturan yang dikuasai anak usia dini melalui media yang diajarkan guru pamong, setelah pembelajaran berimplikasi pada peningkatan perilaku yang lebih baik. Keefektifan terlihat pada keterampilan pragmatik (tuturan/ujaran) anak dalam pembelajaranberlangsung. Pada posisi ini anak asuh mampu memahami bahkan menindaklanjuti tindak tutur yang sampaikan guru pamong. Penguasaan kosa kata tetang bagaimana memiliki sopan santun, bagaimana anak harus bisa mandiri, bisa displin diri, cinta pada tanah air, dan bagaimana mengenal moral dan agama, mampu membawa anak dalam kompetensi pragmatik yang siginikan meningkat dalam berinteraksi (komunikasi).

Keefektifan media hidden card dalam memperbanyak kosa kata dalam upaya mengembangkan penguatan katakter tampak pada kutipan pembelajaran dengan menggunakan bahasa Inggris kode: V1-11/guru-siswa/Bing dan kode: V19/mita-salma/Bing sebagai ragam pembelajaran penguatan integritas pembelajaran bahasa karakter mandiri dan disiplin. Pada kutipan ini, guru pamong berupaya mengenalkan angka 0 sd 10.

Guru-siswa: (k: V1-11/guru-siswa/Bing)

Guru : "eight"

Murid : (mengangkat media angka 8 )

Guru : "two"

Murid : (mengangkat media angka 2)

Guru : "two"

Murid : (mengangkat media angka 2) 
Guru : "three"

Murid : (mengangkat media angka 3)

Guru : "four"

Murid : (mengangkat media angka 4)

Guru : "nine"

Murid : (mengangkat media angka 9)

Guru : "eight"

Murid : (mengangkat media angka 8)

Guru : "one"

Murid : (mengangkat media angka 1)

Guru : "one"

Murid : (mengangkat media angka 1)

Guru :" zero"

Murid : (mengangkat media angka 0)

Guru : "one"

Murid : (mengangkat media angka 1)

Guru : "oke" (bertepuk tangan)

Semua Murid : (ikut bertepuk tangan )

Pada data kode: V1-11/guru-siswa/Bing anak didik dalam proses pembelajaran mengenal angka berbahasa Inggris. Untuk menumbuhkan perilaku baik pada anak yang di mulai sejak dini, guru pamong degan menggunakan media pembelajaran berupaya membantu anak didik mengembangkan potensi diri secara normal dan optimal bertahap dalam berbagai dimensi perkembangan terutama membiasakan anak untuk memiliki inisiatif dan bertanggung jawab sebagi bagian karakter adab mandiri dan disiplin diri.

Siswa Mita dan Salma:

Mita :"hai my friends"

Salma :"hello.."

Mita :"what is your name?"

Salma :"my name is salma, what is your name?"

Mita :"my name is mita"

(salaman lalu tos)

Murid :"sit down please"

Mita :"how are you to day?"

Salma :'i'm alhamdulillah fine thank you." (k: V1-9/mita-salma/Bing)

Begitu juga pada kutipan k: V1-9/mita-salma/Bing tersebut, anak didik dengan media hidden card diajak untuk memeperkenalkan diri di depan kelas. Pada titik kajian ini pembentukan karakter anak didik diterapkan. Pembentukan karakter melalui pembiasaan dengan media melalui pembiasaan yang dilakukan berulang setiap hari dalam kurun waktu yang cukup akan tertanam menjadi karakter bagi anak didik. Pembentukan dilakukan dengan memberikan beberapa contoh tauladan yang diterapkan dalam perikehidupan baik di sekolah maupun di lingkungan anak berada. Pembentukan perkembangan keterampilan berbahasa (pragmatik) melalui pembelajaran hidden card ini bertolak pada titik dasar tahapan pertumbuhan-perkembangan anak usia dini terkait acuan penguatan pendidikan karakter pada etika adap sopan santun, mandiri, disiplin, moral dan agama, serta etika kebersihan dan kesehatan..

Pemberiaan stimulasi sebagai upaya pembinaan kepada anak didik melalui rangsangan pendidikan keterampilan berbahasa dengan media hidden card tribahasa (Bin, Bing, Baja Krama Inggil) berdampak pada percepatan kompetensi pragmatik dalam berkomunikasi dan hasil belajar. Selanjutnya peserta didik usia dini dengan kompetensi dan komprehensinya mempunyai dasar yaang kuat untuk 
memasuki dunia pembelajaran pada tingkat selanjutnya. Keefektifan media lebih lanjut dapat terlihat dari kutipan kemampuan keterampilan berbahasa yang dimiliki anak sebagai berikut.

Pada kutipan (k: V2-7/guru-siswa/Bin) ini menunjukkan ragam penguatan karakter religius (moral dan agama) yang dilakukan dalam kegiatan belajar mengajar dengan menggunakan bahasa Indonesia.

Guru-siswa:

Assalamualaikum

Bila jumpa temanmu

Walaikumsalam

Jawaban yang diucapkan

Bila duduk termenung

Dzikir jangan dilupakan

Agar hati terlindung

Jiwa merasa tentram (k: V2-7/guru-siswa/Bin)

Pada kutipan (k:V2-4/guru-siswa/Bj) ini menunjukkan ragam penguatan pendidikan karakter moral dan agama.

Guru-siswa:

Guru dan murid menyanyikan lagu sugeng enjing bersama-sama

Yen esuk sugeng enjing, $d$

Yen awan sugeng siang,

Yen sore sugeng sonten,

Yen bengi sugeng dalu.

Diparingi matur suwun,

Ditimbali matur dalem,

Yen lewat nderek langkung,

Yen lepat nyuwun pangapunten (k: V2-4/guru-siswa/Bj)

Pada kutipan (k: V2-3/guru-siswa/Bj-Bing-Bin) ini menunjukkan ragam penguatan pendidikan karakter adab sopan santun dan moral di tribahasa (Bin, Bing, Baja Krama Inggil).

Guru-siswa:

Guru dan murid menyanyikan lagu bersama-sama

Lima jari kananku, lima jari kiriku.

Telungkup sejajar, berdiri berhadapan.

Lalu berpelukan, sembunyi dibelakang.

Mari kita hitung berapakah jumlahnya,

Satu,duatigaa.. Empat lima enam,

Tujuh delapan sembilan dan sepuluh.

Kita ulangi dalam bahsa jawa,

Setunggal kaleh tigoo, sekawan gangsal enem,

Pituu woluu songoo sedoso.

Kita ulangi dalam bahasa inggris

One two three.. for five six,

Seeven eight, nine and ten.

Kita ulangi dalam bahasa arab

Wahid isnain tsalas.. arba' khomsah sittah,

Sab'ah tsamaniyah tis'ah 'asyaroh.

Kita ulangi dalam bahasa madura

Settong duwe' tello', empa' lema' ennem,

Petto' bellu' sanga' seppolo.

Guru :"yee tepuk tangan" 
Murid : (bertepuk tangan) (k: V2-3/guru-siswa/Bj-Bing-Bin)

Kutipan data pembelajaran penguatan karakter dengan media visualisasi hidden card yang dilakukan terhadap anak-anak di Taman Kanak-Kanak PKK 1 Bendogerit Kota Blitar ini menunjukkan bahwa perkembangan kemampuan berbahasa (pragmatik) yang dimiliki anak didik meningkat cukup signifikan sesuai berkembang sesuai usia mereka. Percepatan capaian perkembangan anak dalam memahami etika sopan santun, mandiri, disiplin, cinta tanah air, moral dan agama yang diajarkan dan menjadi perilaku pembiasaan di lingkungan sekolah dan di rumah tidak terlepas pada kemampuan anak mendapatkan pemerolehan kosa kata yang cukup pada bidang-bidang kajian tersebut. Semakin banyak kosa kata yang dimiliki anak disik, maka kemampuan pemahaman yang dimiliki anak terhadap apa yang diajarkan guru pamong meningkat, sehingga capaian perkembangan sikap dan perilaku yang menjadi penguatan pendidikan karakter semakin baik. Terlihat bahwa kadaan perkembangan diri pada tahap berkembang sesuai harapan (BSH), perkembangan ke arah kompetensi berkembang sangat baik (BSB) dalam arti sebuah kondisi di mana perkembangan sesuai dengan masa perkembangannya bahkan melebihi usia perkembangannya meningkat. Maknanya, media mampu menguatkan kompetensi pragmatik sehingga mendukung pemahaman penguatan karakter yang ditekankan. Penguatan karakter pembelajaran adab sopan santun, mandiri, disiplin, moral dan agama, serta pembelajaran tentang kebersihan dan kesehatan diri mampu dicerna anak didik.

\section{PEMBAHASAN}

\section{Keefektifan Media Pembelajaran Hidden Card Memperbanyak Kosakata/Tuturan Tiga Bahasa Anak Usia Dini}

Kefektifan media tampak saat kegiatan belajar-mengajar penekanan pada pembiasaan perilaku sederhana dengan hidden card. Media ini merupakan alat perantara/penunjang digunakan guru pamong menyampaikan ide/gagasan sebagai upaya memberikan rangsang berupa stimulus-respon pembiasaan positif pada anak. Realisasi keefektifitasan keberadaan media ini terlihat ketika anak didik Taman Kanak-Kanak PKK 1 dan PKK Pertiwi Kota Blitar mampu memperbanyak kosakata/tuturan tribahasa (Bin, Bing, Baja Krama Inggil) serta mengaplikasikannya dalam bentuk pembiasaan di lingkungan sekolah dan di rumah. Rekapitulasi analisis identifikasi data temuan deskripsi verbal tuturan kompetensi pragmatik keefektifitasan anak didik tersebut teruji dari terdapat peningkatan dalam kosakata/tuturan tribahasa (Bin, Bing, Baja Krama Inggil) serta capaian perkembangan anak. Keefektifan penguasaan kosa kata yang berimplikasi pada kompetensi pragmatik anak mampu memberikan pemahaman terhadap tuturan guru pamong terhadap maksud penguatan pendidikan karakter yang diajarkan melalui pembiasaan dan keteladanan. Pembiasaan perilaku sederhana dengan dibantu media hidden card sesuai perkembangan dan pertumbuhan membawa anak mudah memahami tindak tutur mitar, sehingga anak mampu memahami pesan mitra tutur. Peningkatan tersebut tampak pada kemampuan reseptif dan kemampuan produktif melalui keterampilan berbahasa serta sikap responsif perilaku yang ditunjukkan anak. Capaian pembelajaran tampak pada prosentase hasil capai perkembangan 21 anak (12 laki-laki dan 9 perempuan). Pengamatan capaian perkembangan perubahan karakter anak ini, tampak pada kemampuan anak dalam berinteraksi baik melalui lisan maupun tindakan. Perubahan karakletr meningkat secara signifikan baik dalam hal sopan santun, anak dalam kemandirian, kedisiplinan, rasa cinta tanah air, moral dan keagamaan. Dalam proses ini terdapat anak yang cepat mengalami perubahan dan 
ada yang lamban mengalami perubahan. Tiga guru pamong bersama peneliti melakukan evaluasi bahwa anak yang mengalami capaian yang kurang maksimal tetap dilakukan bimbingan yang lebih baik dan intensif sinergis dengan orang tua asuh.

Capaian perkembangan anak berinteraksi tampak dari kemampuan anak didik menceritakan media hidden card yang dipresentasikan dan anak secara spontan mampu memahami tindak tutur yang terjadi. Guru pamong membimbing berinteraksi mengunakan bahasa sederhana sambil menunjukkan media, sehingga anak tertunjuk mampu mengutarakan ide gagasan, berinteraksi sosial, berhubungan antarpersonal anak didik sesuia media yang dipegangnya. Pada kajian ini kesalahan tatabahasa yang terjadi selama proses interaksi yang dilakukan dalam kegiatan belajar mengajar bukan merupakan hal yang fatal, peneliti melihat fenomena tersebut sebagai sebuah kewajaran dan bersifat alamiah anak belajar bahasa dan belajar berperilaku terpuji.

Melalui pengamatan dan wawancara dengan tiga (3) guru pamong serta (3) pengasuh yang selalu ada di lokasi dengan dibantu supervisor, maka didapatkan hasil evaluasi capaian perkembangan anak didik. Untuk mendapatkan hasil yang cukup valid, maka data di dapat pertama melalui analisis video pembelajaran, berikutnya melalui wawancara terhadap 3 guru pamong yang memahami perkembangan anak sejak sekolah, serta berdialog dengan pengasuh yang notabene selalu berada di lingkungan belajar (menunggui anak asuh).

Hasil perubahan karakter peserta didik anak usia dini TK PKK 1 serta TK PKK Pertiwi Kota Blitar setelah mendapatkan pembelajaran perilaku sederhana dengan media hidden card dalam tiga bahasa sebagai berikut.

\begin{tabular}{|c|c|c|c|c|c|c|c|c|}
\hline \multirow{2}{*}{ No } & \multirow{2}{*}{$\begin{array}{c}\text { CAPAIAN } \\
\text { PERKEMBANGAN } \\
\text { ANAK }\end{array}$} & \multicolumn{7}{|c|}{ PERKEMBANGAN } \\
\hline & & BB & MB & $\%$ & BSH & $\%$ & BSB & $\%$ \\
\hline 1 & $\begin{array}{l}\text { Pembelajaran Adab } \\
\text { Sopan Santun }\end{array}$ & - & - & $4,76 \%$ & 15 & $71,42 \%$ & 5 & $23,80 \%$ \\
\hline 2 & $\begin{array}{l}\text { Pembelajaran } \\
\text { Mandiri }\end{array}$ & - & 1 & $4,76 \%$ & 16 & $76,19 \%$ & 4 & $19,04 \%$ \\
\hline 3 & $\begin{array}{l}\text { Pembelajaran } \\
\text { Disiplin }\end{array}$ & - & 2 & $9,52 \%$ & 14 & $66,66 \%$ & 5 & $23,80 \%$ \\
\hline 4 & $\begin{array}{l}\text { Pembelajaran Moral } \\
\text { Dan Agama }\end{array}$ & - & - & - & 19 & $90,47 \%$ & 3 & $14,28 \%$ \\
\hline 5 & $\begin{array}{l}\text { Pembelajaran } \\
\text { Kebersihan Dan } \\
\text { Kesehatan Diri }\end{array}$ & - & 2 & $9,52 \%$ & 15 & $71,42 \%$ & 4 & $19,04 \%$ \\
\hline
\end{tabular}

Berdasarkan pengamatan peneliti dan guru serta sinergis dengan pengasuh, maka capaian perkembangan yang didapat anak setelah anak semakin banyak memahami kosa kata dapat terdeskripsikan sebagai berikut.

\section{Sopan Santun}

Berdasarkan analisis dari 21 anak asuh dari keseluruhan anak yang diamati didapat 5 anak $(23,80 \%)$ berkembang sangat baik, 15 anak $(71,42 \%)$ berkembang sesuai harapan, 1 anak $(4,76 \%)$ mulai berkembang, dan 0 anak dalam masa belum berkembang. Berdasarkan data dapat dilihat bahwa setelah anak menguasai banyak kosa kata, anak semakain mudah memahami tindak tutur guru pamong dalam pembelajaran pendidikan penguatan karakter etika sopan santun. Terdapat 5 anak yang berkembang sangat baik dalam arti anak tersebut mengalami kondisi perkembangan sikap dan perilaku yang lebih dari masa pertumbuhan dan 
perkembangannya. Sikap rendah hati, menghargai orang lain, santun dengan guru dan orang tua, berbicara lemah lembut, ekspresi tersenyum, serta mengucapkan terima kasih dan minta tolong meningkat. Sikap-sikap ini terlihat ketika subjek lima ini berinteraksi. Bahkan pengasuh menyatakan mereka tertegun ketika anak mereka memperlihatkan perilaku santun, mengucapkan minta tolong dengan bahasa santun ketika si anak meminta bantuan. Data selanjutnya terdapat 15 anak $(71,42 \%)$ berkembang sesuai harapan, maknanya berkembang sesuai harapan, maksudnya pada posisi ini anak mengalami perkembangan yang cukup signifikan di mana anak mengalami pertumbuhan dan perkembangan etika adab sopan santun sesuai dengan perkembangannya. Pada perkembangan etika sopan santun ini terdapat 1 anak $(4,76 \%)$ yang mengalami mulai berkembang, berdasarkan hasil evaluasi si anak mengalami kondisi sakit.

\section{Mandiri}

Pengamatan setelah anak menguasai banyak kosa kata dan memahami tindak tutur mitra dalam pembelajaran di kelas di dapat 4 anak $(19,04 \%)$ berkembang sangat baik, 16 anak $(76,19 \%)$ berkembang sesuai harapan, 1 anak $(4,76 \%)$ mulai berkembang, dan $0 \%$ belum berkembang. Fase kemandirian ini, penguatan karakter lebih ditekankan pada perilaku pada sikap anak yang mencerminkan kemandirian, anak berani mengungkapkan kebutuhan/keinginannya dengan penekanan pada sikap mampu melepas dan memakai sepatunya sendiri, belajar memakai dan melepas baju, serta melepas dan memakai kaos kaki sendiri. Pada tahap ini pembiasaan melepas kaos kaki dan sepatu dan menempatkan pada tempatnya sudah ditekankan sejak akan masuk kelas. Pengasuh pun pembiasaan ini diterapkan, sehingga sifat manja yang dimiliki anak semakin banyak berkurang, sehingga pertumbuhan pada kebiasaan mandiri di dapat anak. Keefektifan media hidden card dalam memperbanyak kosa kata yang dimiliki anak, maka berimplikasi pada proses memudahkan anak memahami maksud pesan yang disampaikan atau diajarkan.

\section{Disiplin}

Capaian perkembangan anak setelah belajar dengan media hidden card tentang bagaimana membiasakan anak untuk mentaati aturan sehari-hari, membiasakan untuk bersikap sabar, dan anak bertanggung jawab adalah 5 anak $(23,80 \%)$ berkembang sangat baik, 14 anak $(66,66 \%)$ berkembang sesuai harapan, 2 anak $(9,52 \%)$ mulai berkembang, dan $0 \%$ belum berkembang. Keefektifan media ini terlihat ketika mereka semakin memehami setelah ditunjukkan berbagai bentuk gambar tentang kedisiplinan. Berikutmya mereka memahami pesan yang disampaikan guru pamong terkait kedisiplinan menuggu antrian, kesabaran berdialog, menaruh barang pada tempatnya. Hasil analisis pembiasaan tampak anak mau mendengarkan ketika guru atau orang lain berbicara, dan meletakkan kembali mainan yang digunakan belajar atau bermain. Di dapat 2 anak $(9.52 \%)$ dalam kondisi mulai berkembang, evaluasi diketahui 1 anak kondisi sakit, dan 1 anak perlu mendapatkan bimbingan khusus.

\section{Moral dan Agama}

Data moral dan agama ini lebih ditekankan pada sikap perilaku mengenal segala kegiatan bentuk beribadah menurut kajian Islam dengan pertimbangan subjek beragam Islam, pembiasaan yang diterapkan pada perilaku akhlak mulai mengucapkan salam dan berdoa serta anjuran melaksanakan sholat lima waktu. Data anak berperilaku berkembang sangat baik 3 anak $(14,28 \%)$ teranalisis orang 
tua sebagai guru agama dan pengaji, sehingga sikap pemahaman pembiasaan moral dan agama lebih baik. Anak dalam kondisi berkembang sesuai harapan, dalam arti berkembang sesuai pertumbuhan secara umum sebesar 19 anak $(90,47 \%)$, dan kondisi anak mulai berkembang sebanyak 2 anak $(9,52 \%)$ teridentifikasi perilaku anak terkondisi sakit dan perlu bimbingan khusus. Tampak bahwa dengan hanya 9,52\% yang dalam masa mulai berkembang perilakunya, maka visualisai hidden card teridentifiksi mampu mempermudah dan memperlancar memberikan pemahaman yang cukup signifikan pada pembelajaran pembiasaan moral dan bentuk keagamaan kepada anak asuh usia dini.

\section{Kebersihan dan Kesehatan Diri}

Pada sesi pra awal pembelajaran, faktor perilaku anak untuk menjaga atau memahami tentang kebersihan dan kesehatan diri serta lingkungan kurang. Anak masih suka membuang bungkus jajanan semaunya walau sekolah telah menyiapkan tempat sampah sesuai jenis sampah, kemudian kebiasaan tidak mencuci tangan sebelum dan sesudah makan pun sering dilakukan anak. Pemahaman anak tentang arti kesehatan dan kebersihan diri serta lingkungan belum menjadi pembiasaan di lingkungan sekolah. Melalui hidden card yang menginformasikan tentang kebersihan dan kesehatan, dengan kosa kata yang sederhana mudah dipahami anak, serta penekanan pembiasaan sikap dan perilaku guru pamong sinergis pengasuh, anak didik mengalami perkembangan yang cukup signifikan. Anak lebih mudah memahami pesan yang disampaikan guru pamong tentang kebersihan dan kesehatan diri. Anak mulai mengetahui cara menempatkan sampah sesuai tempatnya. Sampah basah dan kering sudah bisa membedakan (sampah daur ulang). Sederhana namun anak sudah tertib melakukan cuci tangan dan kaki sebelum masuk kelas, informasi orang tua anak telah melakukan cuci tangan dan kaki sepulang sekolah. Kepedulian tentang sampah meningkat dengan sering mengingatkan teman ketika membuang sampah tidak pada tempatnya. Data anak berkembang sangat baik 4 anak $(19,04 \%)$, anak dalam perkembangan sesuai harapan sebanyak 15 anak $(71,42 \%)$, anak dalam kondisi mulai berkembang sebanyak 2 anak (9,52\%), dan 0\% anak kondisi belum berkembang. Semakin banyak kosa kata yang dipunyai anak, kemampuan pragmatik positif (santun) semakin meningkat dalam berinteraksi.

Keefektifan media hidden card sebagai media visualisasi dalam pembelajaran di kelas maupun di luar kelas membawa anak Taman Kanak-Kanak PKK I dan Pertiwi Kota Blitar mengalami percepatan pemerolehan bahasa sebagai kompetensi pragmatik dalam berkomunikasi. Anak mampu mencerna tindak tutur mitra dalam beromunikasi. Anak terdapat keberanian menyatakan gagasan diri sebagai ungkapan perasaan dan pesaan yang akan disampaikan. Jelas bahwa semakin banyak kosa kata yang dikuasai anak, maka kemampuaan berbahasa (kompetensi pragmatik) semakin meningkat, sehingga anak dengan memahami maksud titndak tutur mitra (guru pamong dan pengasuh). Anak berkomunikasi baik individual maupun dengan mitra tutur, maka anak tersebut mengalami proses pembelajaran keterampilan berbahasa. Maknanya, pada proses tersebut tanpa tersadari anak mengalami pembelajaran bahasa termasuk penguasaan komponen serta aturan kebahasaan di antaranya sistem bunyi, fonologi, tata bahasa, kosakata, beserta sisten pemakaian bahasanya. Termasuk di dalamnya penguasaan pragmatik anak yang dimungkinkan anak usia dini dalam berkomunikasi mampu

336 BRILIANT: Jurnal Riset dan Konseptual Volume 5 Nomor 2, Mei 2020 
menentukan kosa kata yang tepat untuk menyampaikan ide daan gagasn dirinya sesuai tujuannya, Sulchan (2011: 1.27-1.28).

Berdasarkan hasil analisis rekapitulasi tersebut membuktikan bahwa media hidden card mampu menunjukkan keefektifannya dalam pemerolehan bahasa. Selanjutnya, penguasaan bahasa yang baik anak mudah memahami maksud tindak tutur dalam upaya penguatan pendidikan karakter dan anak didik berani mengungkapkan maksud, gagasan, dan pemikirannya baik secara personal maupun kelompok. Aplikasi penerapan media hidden card mampu membentuk keutuhan kepribadian, meningkatkan kualitas pertumbuhan dan perkembangan pada masa kanak-kanak yang sifatnya mendasar untuk berbagai aspek khususnya kemampuan pragmatik anak didik sejak dini (maksimal capaian perkembangan diri). Anak-anak usia dini Taman Kanak-Kanak PKK 1 mampu melakukan proses konstruksi kreatif dalam pemerolehan bahasa dalam upaya memperbanyak penguasaan kosa kata sebagai kompetensi pragmatik dalam berkomunikasi. Pragmatik yang dimiliki anak meningkat seiring banyaknya kosa kata yang dimiliki sebagai pengalaman (komprehensif) tindak tutur dalam berinteraksi bersama lingkup pemakai bahasa. Media hidden card tiga bahasa yang bervariasi, menarik bentuknya, menarik warna kartunya, dan mudah dipahami anak, membawa anak lebih cepat terampil berkomunikasi. Dari 21 anak (21 anak (12 laki-laki dan 9 perempuan) siswa didik usia dini TK PKK 1 Bendogerit Kota Blitar terjadi peningkatan kompetensi pragmatiknya. Hal tersebut tampak pada adanya kemampuan memahami, stimulus-respon tindak tutur guru pamong maupun mitra tutur lain yang terimplikasikan pada pembiasaan yang terdeteksi melalui pengamatan capaian perkembangan pendidikan penguatan karakter. Anak asuh usia dini menunjukkan perubahan yang baik dalam etika sopan santun sebanyak 5 anak $(23,80 \%)$ berkembang sangat baik, 15 anak $(71,42 \%)$ berkembang sesuai harapan, 1 anak $(4,76 \%)$ mulai berkembang, dan 0 anak dalam masa belum berkembang; etika mandiri sebanyak 4 anak $(19,04 \%)$ berkembang sangat baik, 16 anak $(76,19 \%)$ berkembang sesuai harapan, 1 anak $(4,76 \%)$ mulai berkembang, dan $0 \%$ belum berkembang; etika disiplin diri sebanyak 5 anak $(23,80 \%)$ berkembang sangat baik, 14 anak $(66,66 \%)$ berkembang sesuai harapan, 2 anak $(9,52 \%)$ mulai berkembang, dan $0 \%$ belum berkembang; etika moral dan agama, anak berperilaku berkembang sangat baik 3 anak (14,28\%), kondisi berkembang sesuai harapan, dalam arti berkembang sesuai pertumbuhan secara umum sebesar 19 anak $(90,47 \%)$, dan kondisi anak mulai berkembang sebanyak 2 anak $(9,52 \%)$ teridentifikasi perilaku anak terkondisi sakit dan perlu bimbingan khusus; dan etika kebersihan dan kesehatan diri teridentifikasi bahwa anak berkembang sangat baik 4 anak $(19,04 \%)$, anak dalam perkembangan sesuai harapan sebanyak 15 anak $(71,42 \%)$, anak dalam kondisi mulai berkembang sebanyak 2 anak (9,52\%), dan 0\% anak kondisi belum berkembang. Jelas bahwa, peningkatan kompetensi pragmatik ada, jika anak memiliki banyak unsur kosa kata yang komplek sebagai komprehensifnya. Semakin banyak kosakata yang dipunyai anak, maka kemampuan berinteraksi semakin meningkat. Dikatakan hidden card efektif mengkongkritkan tindak tutur lisan ke dalam bentuk kongkrit gambar, maka guru pamong dengan metode partisipan dan tanya jawab mengajak anak didik berperan aktif sesuai subtema berpartisipasi dari bentuk komunikasi lisan ke dalam pembelajaran nyata yang tertuang dalam tumpukan media hidden card. Interaksi yang maksimal guru dan siswa dalam kegiatan belajar-mengajar 
mampu menjadi penentu keberhasilan kompetensi pragmatik anak. Hidden card sebagai daya tangkap, daya simpan yang dapat mendeskripsikan ulang kepada anak belajar sesuai tema/subtema.

Implikasi hidden card sebagai media pembelajaran pemerolehan bahasa upaya memperbanyak kosakata tribahasa (Bin, Bing, Baja Krama Inggil) penguat karakter budaya lokal adalah terdapatnya percepatan anak didik memperoleh berbagai kosa kata. Pemerolehan bahasa yang kompleks diperoleh anak, maka kemampuan berbahasa anak meningkat terutama kemampuan pragmatik dan berkomunikasi. Kenampakan keefektifan media terkaji dari kompetensi pragmatik anak dalam berkomunikasi tindak tutur sebagai produk tuturan semakin kompleks meningkat. Semakin meningkat kompetensi pragmatik, maka perubahan karakter yang terjadi, anak didik usia dini TK PKK I dan Pertiwi semakin paham dan mampu memulai ucapkan dan membalas salam, mengucapkan terima-kasih, meminta dan memihon maaf, meniru gerakan berdoa, mengucapkan doa-doa sebelum dan/atau sesudah melakukan berbagai hal, menyatakan perasaan pada guru Pamong dalam variasi tribahasa (Bin, Bing, Baja Krama Inggil) , berbagi peran dalam suatu permainan. Bagi pendidik atau guru Pamong dengan melihat perkembangan anak didik berdasarkan in put peserta didik diperlukan pengembangan media pembelajaran yang relevan dengan berpijak pada program penguatan pendidikan karakter abak usia dini. Diperlukannya sebuah media hidden card yang mampu mengimplikasikan pada materi pada tema/subtema bernilai karakter yang telah dituangkan dalam Kurikulum.

\section{KESIMPULAN}

Berdasarkan kajian dan hasil pembahasan, media hidden card merupakan salah satu bagian media pembelajaran yang berfungsi menyampaikan ide/gagasan sebagai pesan edukasi. Keefektifan pemakaian hidden card tribahasa (Bin, Bing, Baja Krama Inggil), mampu meningkatkan kompetensi pragmatik anak usia dini, maknanya hidden card mampu mendorong anak usia dini lebih cepat memahami kefaktaan sesuai tema/subtema dan percepatan penguasaan kosa kata. Pengalaman bermakna tersebut, anak didik usia dini TK PKK I dan Pertiwi mendapatkan kemudahan mempelajari topik/subtopik pembelajaran yang bersifat lisan/abstrak ke dalam bentuk nyata (gambar), anak tidak terperosok pada argumentasi daan bayangan benda yang dimaksudkan dalam lisan yang disampaikan guru pamong.

Media hidden card sebagai wahana visual (gambar) mampu menempatkan diri sebagai salah satu media/alat pembelajaran yang dapat meningkatkan stimulus visual seperti mengingat, mengenali, mengingat kembali, menghubungkan antara konsep dan fakta, serta mampu memberikan stimulus secara verbal. Karakteristik media hidden card ini dapat dikaji keefektifannya berdasarkaan peningkatan hasil akhir pemerolehan kompetensi pragmatik anak usia dini. Kelebihan media hidden card terletak pada sisi rangsangan secara visual, selanjutnya mampu memberikan daya tarik pada anak didik usia dini subjek dan praktiknya memberikan stimulus-respon dalam pembelajaran. Hidden card mampu memberikan motivasi belajar yang tinggi dalam meningkatkan kualitas kompetensi pragmatik anak prasekolah dalam pembelajaran kosa kata tribahasa (Bin, Bing, Baja Krama Inggil), dan meningkatkan suasana kelas semakin hidup.

338 BRILIANT: Jurnal Riset dan Konseptual

Volume 5 Nomor 2, Mei 2020 
Tantangan peningkatan kualitas kompetensi pragmatik dalam berkomunikasi pada TK PKK I dan Pertiwi Kota Blitar ini terletak pada faktor yakni (1) terdapatnya sifat verbalis, maknanya terdapat kemampuan pada anak didik usia dini peningkatan mengatakan/menyebutkaan berbagai kosa kata secara lisan, namun pada dasarnya mereka tidak memahami secara mendasar arti sebenarnya. Analisis data pendukung melalui pengamatan dan wawancara bahwa hal tersebut terjadi disebabkan guru pamong dalam pembelajaran dengan media hidden card tribahasa (Bin, Bing, Baja Krama Inggil) menggunakan metode ceramah, memberikan penjelasan sekedarnya dengan menunjukkan media hidden card, selanjutnya anak didik dalaam masa pertumbuhan dan perkembangannya memiliki kecenderungan sekedar menjiplak/menirukan kata yang diucapkan guru pamong; (2) perilaku kesalahan dalam menafsirkan pada diri anak, maksudnya terdapat beberapa peristilahan atau kosa kata yang disampaikan secara lisan tanpa tampilan media pembelajaran diartikan/terdefinisikan berbeda oleh anak; dan (3) terdapatnya perilaku menyimak tidak terpusat yang disebabkan anak dalam kondisi (tidak sehat/sakit), terdapat fokus lain yang menarik perhatian anak, anak melamun, anak bermain sendiri, lebih terpusat pada pengasuh yang berada dalam ruang kelas dan kurang pengawasan dan bimbingan guru. Berdasarkan hasil analisis rekapitulasi tersebut membuktikan bahwa media hidden card mampu meningkatkan kualitas kompetensi pragmatik anak prasekolah dalam pembelajaran kosa kata yang mampu mengungkapkan maksud, gagasan, dan pemikiran program penguatan karakter yang dicanangkan Taman Kanak-Kanak PKK 1 dan PKK Pertiwi Kota Blitar.

\section{SARAN}

Asesemen teori, kajian ini berimplikasi terhadap proses pengembangan keterampilan berbahasa, strategi pemerolehan bahasa, khususnya pencapaian pemerolehan kompetensi pragmatik anak dengan media hidden card sebagai media pembelajaran pemerolehan bahasa. Asesmen praktis, media hidden card tribahasa (Bin, Bing, Baja Krama Inggil) sebagai media pembelajaran pemerolehan bahasa dapat digunakan sebagai rujukan bagi guru untuk meningkatkan kualitas pengajaran berbahasa khususnya dengan mengedepankan keterampilan berbahasa, meningkatkan motivasi, keaktifan, minat, bakat, dan keberanian anak didik dalam keterampilan berbahasa sehingga dapat meningkatkan perkembangan jiwa anak didik dalam berkomunikasi. Bagi lembaga pendidikan, khususnya lembagaga pendidikan prasekolah (Taman Kanak-kanak) hasil penelitian ini bermanfaat sebagai salah satu bahan pertimbangan atau masukan tentang pengembangan model media pembelajaran dan strategi pembelajaran bahasa untuk meningkatkan karakter anak.

\section{DAFTAR RUJUKAN}

Khaironi, Mulianah. 2017. Pendidikan Karakter Anak Usia Dini. jurnal Golden Age Universitas Hamzanwadi; vol. 01 No. 2, Desember 2017, Hal. 82-89. E-ISSN: 2549-7367.

Khaironi, Mulianah. 2018. Perkembangan Anak Usia Dini. Jurnal Golden Age Hamzanwadi University, Vol. 3 No. 1, Juni 2018, Hal.1-12, E-ISSN: 25497367). 
Prasanti dan Fitriani. 2018. (Pembentukan Karakter Anak Usia Dini: Keluarga, Sekolah, Dan Komunitas? (Studi Kualitatif tantang Pembentukan Karakter Anak Usia Dini Melalui Keluarga, Sekolah, dan Komunitas. Jurnal obsesi: Jurnal Pendidikan anak Usia Dini, Research \& Learning in Early Childhood Education, vol 2 No 1 (2018) Page 13-19). https://obsesi.or.id/index.php/obsesi).

Prismatasair, Puspitowati, Pipit. 2019. Penerapan Model Pembelajaran Berbasis Pengalaman (Experiential Learning) dengan Menggunakan Media Gambar dalam Pembelajaran Menulis Karangan Deskripsi pada Siswa Kelas IV MI Riyalatul Uqul. Linguista: Jurnal Ilmiah Bahasa, Sastra, dan Pembelajarannya.

Otto, Beverly. 2015. Perkembangan Bahasa Anak Usia Dini. Jakarta: Prenada Media.

Rida Sinaga. 2018. Pendidikan Karakter Pada Anak Usia Dini, Societas Dei, vol. 5, No. 2, Oktober 2018.

Sadiman, S.A. 2002. Media Pendiidikan. Pengertian, Pengembangan dan Pemanfaatan. Jakarta: Raja Grafindo P.

Satyasa, I Wayan. 2007. Landasan Konseptual Media Pembelajaran.Workshop Media Pembelajaran bagi Guru-guru SMA Negeri Banjar Angkan Pada Tanggal 10 Januari 2007 di Banjar Angkan Klungkung.

Solchan, TW. 2011. Materi Pokok Pendidikan Bahasa Indonesia. Jakarta: UT.

Zubaida. 2016. Implemntasi Pendidikan Karakter Anak Usia Dini. Jurnal Madaniyah, Vol. 1 Edisi X Januari 2016, ISSN 2086-3462 